\title{
Efficient arsenic(III) removal from aqueous solution by a novel nanostructured iron-copper-manganese trimetal oxide
}

\author{
Gaosheng Zhang a,*, Ye Liu ${ }^{\mathrm{a}}$, Jianyan Wang ${ }^{\mathrm{b}}$, Huosheng $\mathrm{Li}^{\mathrm{a}}$

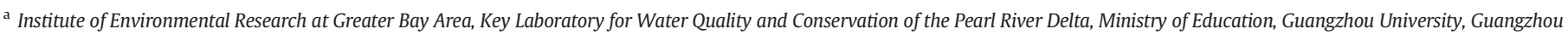 \\ 510006, China \\ b Key Laboratory of Coastal Environmental Processes and Ecological Remediation, Yantai Institute of Coastal Zone Research (YIC), Chinese Academy of Sciences (CAS), Yantai 264003, China
}

\section{A R T I C L E I N F O}

\section{Article history:}

Received 9 December 2019

Received in revised form 11 March 2020

Accepted 24 March 2020

Available online 16 April 2020

\section{Keywords:}

Fe-Cu-Mn trimetal oxide

Arsenite

Sorption

Oxidation

Removal

\begin{abstract}
A B S T R A C T
The removal of arsenite [As(III)] has attracted increasing attentions because it is higher toxic and more difficult to be removed from water than arsenate $[\mathrm{As}(\mathrm{V})]$. For efficient $\mathrm{As}(\mathrm{III})$ uptake, a nanostructured iron-coppermanganese trimetal oxide (ICM) was therefore synthesized using a simultaneous oxidation and coprecipitation approach at room temperature. The as-prepared ICM exhibits multifunctional properties, which can not only oxidize effectively As(III) but also sorb the produced $\mathrm{As}(\mathrm{V})$. The maximal sorption capacity of As (III) reaches up to $131 \mathrm{mg} / \mathrm{g}$ under neutral conditions, which outperforms the majority of adsorbents reported in the literature. The As(III) sorption drops gradually as solution $\mathrm{pH}$ increases. However, it is not significantly influenced by ionic strength and present anions except for $\mathrm{PO}_{4}^{3-}$, implying a relatively high selectivity. The active sorption sites of spent ICM can be easily restored through $\mathrm{NaOH}$ solution treatment. The removal of As(III) is a complicated process involving in both oxidation and adsorption, in which inner-sphere surface complexes are formed. The oxidation of $\mathrm{As}(\mathrm{III})$ to $\mathrm{As}(\mathrm{V})$ is mainly ascribed to the Mn oxide content in composite, whereas the adsorption of formed $\mathrm{As}(\mathrm{V})$ is predominately attributed to the Fe oxide and $\mathrm{Cu}$ oxide. The ICM might act as a promising alternative to remove arsenic from groundwater and wastewater, due to its good performance, low cost, facile synthesis and high reusability.
\end{abstract}

(c) 2020 Elsevier B.V. All rights reserved.

\section{Introduction}

As a global problem, arsenic pollution in groundwater is extensively concerned because long-term exposure to arsenic-containing drinking water may cause cancer and other severe noncancer effects [1-3]. To minimize the health risk associated with arsenic in drinking water, many countries and districts have employed a stringent standard of $0.01 \mathrm{mg} / \mathrm{L}$ as the maximum permissible level of arsenic.

Inorganic arsenic predominates in natural waters and occurs mostly in two forms, $\mathrm{As}(\mathrm{V})$ and $\mathrm{As}(\mathrm{III})$. The former is the major species in welloxygenated water, whereas the latter may be the dominant species in reducing groundwater. For example, the $\mathrm{As}(\mathrm{III}) / \mathrm{As}_{\mathrm{T}}$ ratios in groundwater from Inner Mongolia, China are normally in the range of 0.6-0.9 [4]. Moreover, As(III) is higher toxic (25-60 times) [5] and more difficult to be removed from water than $\mathrm{As}(\mathrm{V})$ [6,7]. Adsorption technology is believed to be one of the most promising methods for removing arsenic from water owing to its simple operation, affordable cost, potential for regeneration, and little toxic sludge generation [8,9]. However, most traditional adsorbents such as alumina and activated carbon are

\footnotetext{
* Corresponding author.

E-mail addresses: gszhang@gzhu.edu.cn, gszhang@yic.ac.cn (G. Zhang).
}

effective for $\mathrm{As}(\mathrm{V})$ adsorption, but less effective in removing $\mathrm{As}(\mathrm{III})$. In order to get better removal of arsenic, a preoxidation of As(III) to As (V) treatment is usually conducted prior to adsorption. Nevertheless, the pretreatment process makes the operation more complicated and uneconomical. Hence, it is essential to develop more efficient and affordable adsorbents for As(III) removal.

Many transition metal oxides and hydroxides, such as iron (hydr) oxides, titania, hydrous cerium oxide, manganese dioxide, zirconia and cupric oxide, have been utilized to remove As(III) from water, due to their high affinity [10-16]. Composites containing two or three metal (hydr)oxides have attracted considerable attention in the last ten years, since they exhibit much higher efficiency in removing As(III) than single oxides in virtue of synergistic effect. Several binary metal (hydr)oxides such as Fe-Mn binary oxide [17], Ce-Ti binary oxide [18], Zr-Mn binary oxide [19], Fe-Ni binary oxide [20] and Ce-Mn binary oxide [21] were prepared and showed high performance for As(III) uptake. In addition, some ternary metal oxides were synthesized for enhanced As(III) removal. For examples, Thanh et al. prepared a nanosized Al-Ti-Mn trimetal oxide for simultaneous As(III) and As (V) removal [22]; Penke et al. synthesized a Co-Al-Fe ternary metal oxide to remove both $\mathrm{As}(\mathrm{III})$ and $\mathrm{As}(\mathrm{V})$ [23]; Nasir et al. reported a FeNi-Mn trimetal oxide for efficient As(III) removal [24]; Zhang et al. 
developed a multifunctional Fe-Ti-Mn trimetal oxide to enhance the removal of both As(III) and As(V) [25]; Lin et al. prepared a Fe-Mn-La impregnated biochar composite to effectively remove As(III) [26].

Previously, an iron-copper ( $\mathrm{Fe}-\mathrm{Cu}$ ) binary oxide was fabricated in our lab, which was found to have rather high arsenic sorption capacity [27]. Moreover, this composite demonstrated high effectiveness in removing $\mathrm{As}(\mathrm{V})$ at very low concentration. However, it was less effective for As(III) removal at low concentration level. Typically, the arsenic concentration in groundwater varies greatly from less than $10 \mu \mathrm{g} / \mathrm{L}$ to several hundred $\mu \mathrm{g} / \mathrm{L}[4]$. From the practical point of view, adsorbents that have high efficiency in removing both $\mathrm{As}(\mathrm{V})$ and $\mathrm{As}(\mathrm{III})$ at trace level, will attract much more attention. $\mathrm{MnO}_{2}$ is a moderate oxidizing agent and can effectively oxidize $\mathrm{As}(\mathrm{III})$ to $\mathrm{As}(\mathrm{V})$ [28-31]. It can be anticipated that the incorporation of $\mathrm{MnO}_{2}$ into the $\mathrm{Fe}$-Cu binary oxide system would enhance trace As(III) removal. However, to our best knowledge, the fabrication of iron-copper-manganese trimetal oxide (ICM) sorbent to effectively remove As(III), has never been reported.

Hence, the main objectives of this research were (1) to fabricate the ICM via a facile oxidation coupled with co-precipitation method; (2) to characterize the obtained ICM with a variety of techniques; (3) to evaluate its effectiveness in As(III) removal at both high and low concentration levels and finally (4) to examine its reusability and the possible removal mechanism.

\section{Materials and methods}

\subsection{Materials}

Potassium permanganate $\left(\mathrm{KMnO}_{4}\right)$, iron(II) sulfate heptahydrate $\left(\mathrm{FeSO}_{4} \cdot 7 \mathrm{H}_{2} \mathrm{O}\right)$, copper sulfate pentahydrate $\left(\mathrm{CuSO}_{4} \cdot 5 \mathrm{H}_{2} \mathrm{O}\right)$, sodium hydroxide $(\mathrm{NaOH})$, sodium hydrogen arsenate heptahydrate $\left(\mathrm{Na}_{2} \mathrm{HAsO}_{4} \cdot 7 \mathrm{H}_{2} \mathrm{O}\right)$, arsenic trioxide $\left(\mathrm{As}_{2} \mathrm{O}_{3}\right)$, sodium nitrate $\left(\mathrm{NaNO}_{3}\right)$, sodium chloride $(\mathrm{NaCl})$, sodium sulfate $\left(\mathrm{Na}_{2} \mathrm{SO}_{4}\right)$, sodium carbonate $\left(\mathrm{Na}_{2} \mathrm{CO}_{3}\right)$, sodium metasilicate nonahydrate $\left(\mathrm{Na}_{2} \mathrm{SiO}_{3} \cdot 9 \mathrm{H}_{2} \mathrm{O}\right)$ and sodium phosphate dodecahydrate $\left(\mathrm{Na}_{3} \mathrm{PO}_{4} \cdot 12 \mathrm{H}_{2} \mathrm{O}\right)$ were of analytical grade and were used directly. All vessels were cleaned using a dilute $\mathrm{HNO}_{3}$ solution (1\%) and then deionized water before use. The stock solution containing $\mathrm{As}(\mathrm{V})$ was prepared by dissolving $\mathrm{Na}_{2} \mathrm{HAsO}_{4} \cdot 7 \mathrm{H}_{2} \mathrm{O}$ into deionized water and stock solution containing $\mathrm{As}(\mathrm{III})$ was prepared by dissolving $\mathrm{As}_{2} \mathrm{O}_{3}$ into dilute $\mathrm{NaOH}$ solution.

\subsection{Preparation of iron-copper-manganese trimetal oxide}

The ICM was fabricated according to a modified method described by Zhang et al. [17]. The detailed fabrication procedure was provided in the Supplementary material.

\subsection{Characterization of ICM}

The morphology of ICM was analyzed with a field scanning electron microscope (SEM, Hitachi S-4800, Japan) and a high-resolution transmission electron microscope (TEM, JEOL JEM-2100, Japan). The specific surface area was determined by a surface area analyzer (Micromeritics ASAP 2020, USA). A D/Max 2500 V diffractometer (Rigaku Co., Japan) was used to collect the X-ray powder diffraction data. A zeta potential analyzer (Nano-ZS90, Malvern, UK) was employed to measure the zeta potentials of ICM before and after reaction with As(III). Fourier transform infrared (FTIR) spectra were recorded using a Nicolet IS10 FTIR spectrophotometer (Thermo scientific, USA). The X-ray photoelectron spectra (XPS) measurements were performed on a Kratos Axis Ultra DLD spectroscopy (Kratos, UK).

\subsection{Arsenic sorption experiments}

A series of batch experiments were carried out to evaluate the performance of arsenic sorption by ICM. A known amount of ICM was put into 100 -ml polyethylene bottles containing $50 \mathrm{ml}$ arsenic solution of different concentrations. The sealed bottles were then vibrated on an orbit shaker at $170 \mathrm{rpm}$ for $24 \mathrm{~h} .0 .1 \mathrm{M} \mathrm{NaOH}$ and/or $\mathrm{HNO}_{3}$ were used to adjust the $\mathrm{pH}$ of solutions. A desired amount of $\mathrm{NaNO}_{3}, \mathrm{NaCl}$, $\mathrm{Na}_{2} \mathrm{CO}_{3}, \mathrm{Na}_{2} \mathrm{SO}_{4}, \mathrm{Na}_{2} \mathrm{SiO}_{3}$ or $\mathrm{Na}_{3} \mathrm{PO}_{4}$ was added for experiments examining the influence of ionic strength or coexisting anions. After reaction, all samples collected were treated through filtration using $0.45 \mu \mathrm{m}$ membrane and then were analyzed for arsenic. More detailed description of sorption experiments can be seen in the Supplementary material.

\subsection{Regeneration and reuse of ICM}

To examine the reusability of ICM, successive sorption-desorption tests were performed. A defined amount of $200 \mathrm{mg}$ ICM was loaded to a beaker containing $1000 \mathrm{ml}$ solution of $10 \mathrm{mg} / \mathrm{L} \mathrm{As(III).} \mathrm{After} \mathrm{shaking}$ for $12 \mathrm{~h}$, the exhausted ICM was separated by filtration from the solution and the filtrate was collected for further arsenic analysis. The collected ICM was then dried at $65{ }^{\circ} \mathrm{C}$ for $24 \mathrm{~h}$. After that, the arsenicloaded ICM was transferred to a bottle containing $50 \mathrm{ml} \mathrm{NaOH}$ solution of $0.5 \mathrm{M}$. After shaking for $4 \mathrm{~h}$, the ICM was separated from the $\mathrm{NaOH}$ solution, washed several times with deionized water and then dried at $65{ }^{\circ} \mathrm{C}$ for $24 \mathrm{~h}$. The regenerated ICM was employed in the next sorption-desorption cycle.

\subsection{Analytical methods}

Concentration of arsenic in solution was analyzed by an inductively coupled plasma mass spectrometry machine (ICP-MS, ELAN DRC II, Perkin Elmer Co. USA) [27].

\section{Results and discussion}

\subsection{Characterization of ICM}

The SEM image of ICM is shown in Fig. 1a. Apparently, the ICM appears as aggregates of nanoparticles, which makes the surface rough. The TEM image (Fig. 1b) displays that the shape of the nanoparticles is nonuniform and the size of nanoparticles is $30-60 \mathrm{~nm}$. The XRD pattern of ICM at $2 \theta$ ranging from $5^{\circ}$ to $90^{\circ}$ is illustrated in Fig. S1 (Supplementary material). No distinct peaks are observed, except for two weak and broad peaks at around 35.8 and $62.1^{\circ}$, respectively. It implies that the ICM is noncrystalline and similar to those of $\mathrm{Fe}-\mathrm{Cu}$ binary oxide and 2-line ferrihydrite [27]. BET analysis demonstrates that the ICM possesses a specific surface area of $162 \mathrm{~m}^{2} / \mathrm{g}$ with a total pore volume of $0.59 \mathrm{~cm}^{3} / \mathrm{g}$. The specific surface area is much less than that of the FeMn binary oxide $\left(265 \mathrm{~m}^{2} / \mathrm{g}\right)$ and Fe-Cu binary oxide $\left(282 \mathrm{~m}^{2} / \mathrm{g}\right)$. However, the total pore volume is higher than that of them ( 0.47 and $0.31 \mathrm{~cm}^{3} / \mathrm{g}$, respectively) [27,32].

\subsection{Sorption behavior}

\subsubsection{Sorption isotherms}

The ICM demonstrates rather high sorption capacities of arsenic at high equilibrium concentration (Fig. 2a), indicating its effectiveness in arsenic uptake. In addition, the maximal sorption capacity of $\mathrm{As}(\mathrm{III})$ is much higher than that of $\mathrm{As}(\mathrm{V})$, which is beneficial for As(III) removal and consistent with the results of the Fe-Mn and Fe-Cu binary oxide [27,32]. Effectiveness of arsenic removal at trace levels was further evaluated and Fig. $2 \mathrm{~b}$ depicts the results. As seen, the efficiency of As(III) removal is almost same as $\mathrm{As}(\mathrm{V})$ at equilibrium concentration lower than $0.15 \mathrm{mg} / \mathrm{L}$. Obviously, the ICM is also effective in removing As(III) at trace levels, which facilitates its application in real drinking water treatment and meets the goal of this research. Moreover, the nearly identical removal efficiency suggests that the As(III) has been completely oxidized to $\mathrm{As}(\mathrm{V})$ by the ICM at low concentration. 

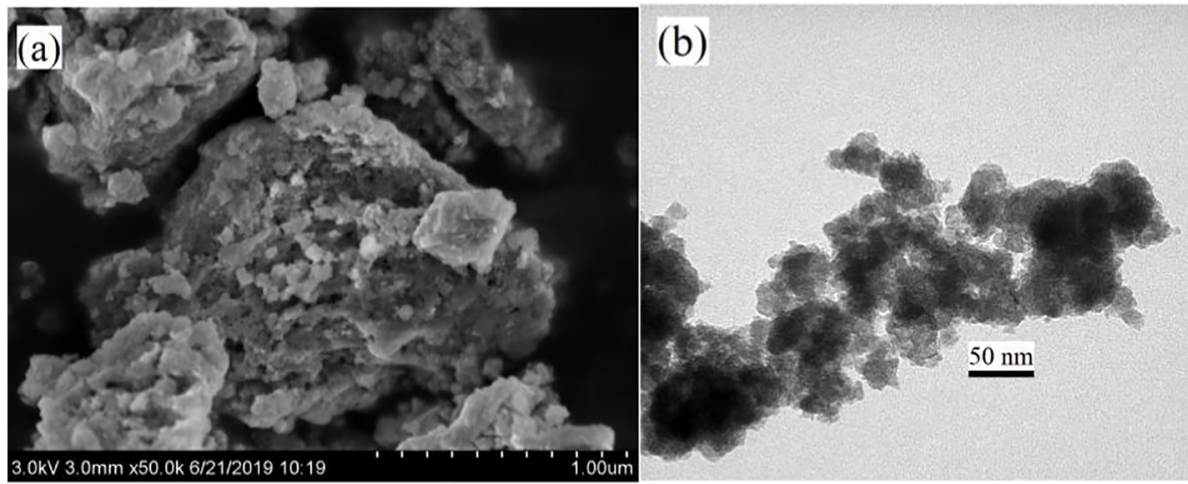

Fig. 1. SEM image (a) and TEM image (b) of the Fe-Cu-Mn trimetal oxide.

The Langmuir model (Eq. (1)) and Freundlich model (Eq. (2)) were applied to fit the experimental data obtained at high equilibrium concentration.

$q_{e}=\frac{q_{\max } b C_{e}}{1+b C_{e}}$

$q_{e}=K_{F} C_{e}^{n}$
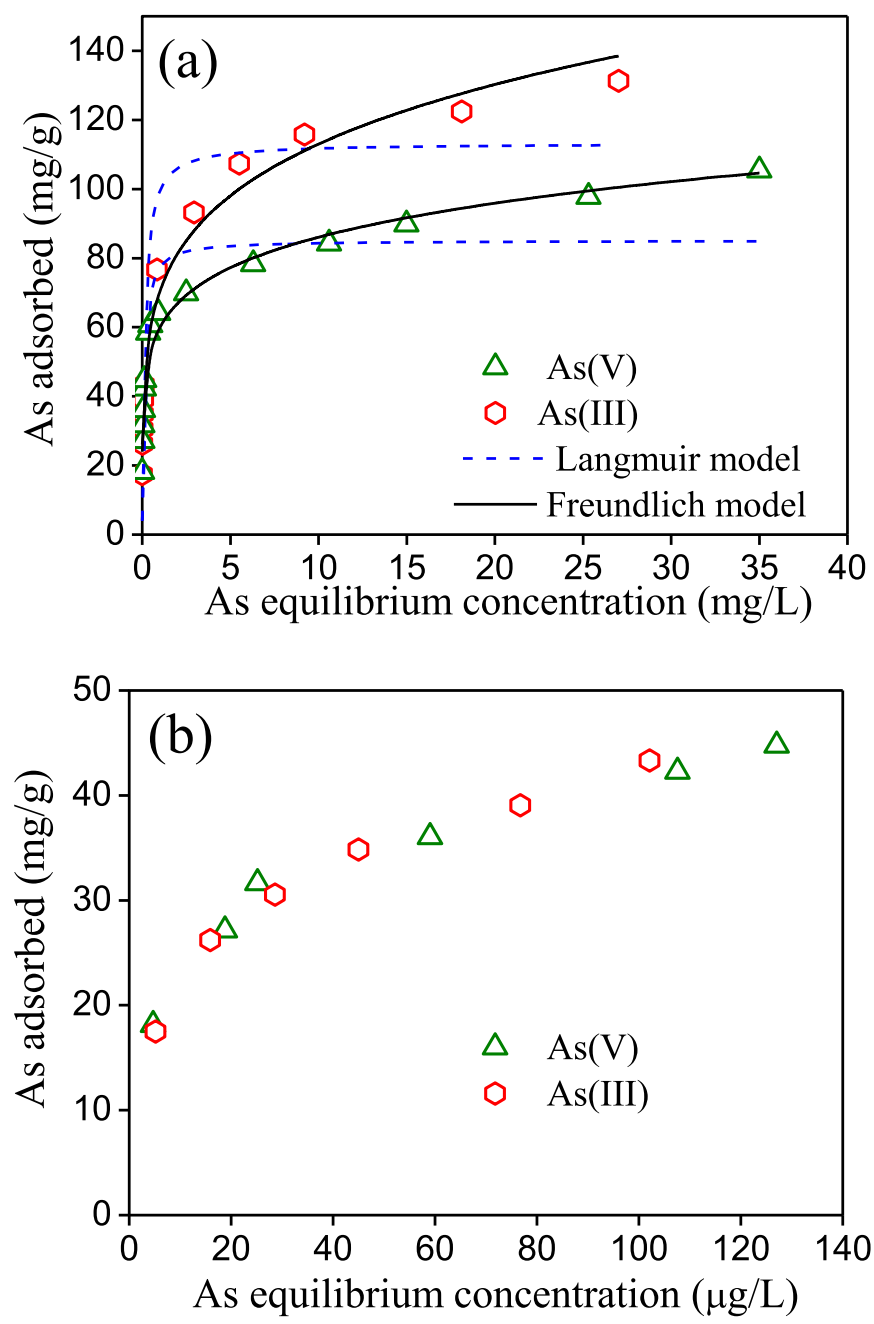

Fig. 2. Sorption isotherms of arsenic on the Fe-Cu-Mn trimetal oxide at $\mathrm{pH} 7.0 \pm 0.1$ (a) high equilibrium concentration and (b) low equilibrium concentration. where $q_{\mathrm{e}}$ represents the amount of arsenic adsorbed on the surface ( $\mathrm{mg}$ / $\mathrm{g}), q_{\max }$ represents the maximal adsorption capacity for complete monolayer coverage $(\mathrm{mg} / \mathrm{g})$, Ce is the equilibrium concentration of arsenic $(\mathrm{mg} / \mathrm{L}), b$ and $K_{F}$ are the adsorption constants from Langmuir model and Freundlich model, respectively.

The regression coefficients for $\mathrm{As}(\mathrm{III})$ and $\mathrm{As}(\mathrm{V})$ obtained from the Freundlich model are 0.981 and 0.972 , respectively, which are remarkably higher than those from the Langmuir model (Table 1). This indicates that the experimental data are better fitted by the Freundlich model. It is no surprise that the Langmuir model cannot well describe the sorption behavior, because it supposes that sorption takes place on a surface with high homogeneity and no oxidation reaction is involved on the solid surface. The Freundlich model is suitable to describe sorption where the material possesses a heterogeneous surface. The surface of ICM is obviously heterogeneous, owing to the concurrence of iron, $\mathrm{cu}-$ pric and manganese. Additionally, As(III) oxidation by the ICM occurred during its sorption. Thus, the maximal sorption capacity $\left(\mathrm{q}_{\max }\right.$ ) obtained from the Langmuir model could not represent the real value. The reliable values of $\mathrm{q}_{\max } \mathrm{As}(\mathrm{V})$ and $\mathrm{q}_{\max } \mathrm{As}(\mathrm{III})$ are 105 and $131 \mathrm{mg} / \mathrm{g}$, respectively, which are directly obtained from the graphic (corresponding to the isotherm plateau). The potential of ICM was evaluated by comparing the maximal sorption capacity of arsenic with various adsorbents reported in the literatures. As can be seen in Table 2, the ICM outperforms many other sorbents.

\subsubsection{Sorption kinetics}

The influence of contact time on As(III) sorption by the ICM is exhibited in Fig. 3. The As(III) removal was rather fast within $2 \mathrm{~h}$ and almost $85 \%$ of equilibrium uptake capacity was accomplished, which might be ascribed to the smaller particle size and higher specific surface area of the ICM. Then, the sorption of As(III) slowed down and sorption equilibrium was reached at about $24 \mathrm{~h}$.

Kinetic data were initially fitted by the pseudo-first-order model (Eq. (3)) and pseudo-second-order model (Eq. (4)).

$$
\begin{aligned}
& q_{\mathrm{t}}=q_{\mathrm{e}}\left(1-\mathrm{e}^{-k_{1} t}\right) \\
& q_{\mathrm{t}}=\frac{q_{\mathrm{e}}{ }^{2} k_{2} t}{1+q_{\mathrm{e}} k_{2} t}
\end{aligned}
$$

Table 1

Langmuir and Freundlich isotherm parameters for $\mathrm{As}(\mathrm{V})$ and $\mathrm{As}(\mathrm{III})$ sorption on Fe-CuMn trimetal oxide at $\mathrm{pH} 7.0 \pm 0.1$.

\begin{tabular}{lccllllll}
\hline \multicolumn{2}{l}{ Langmuir model } & & & \multicolumn{3}{l}{ Freundlich model } \\
\cline { 1 - 2 } As species & $q_{m}(\mathrm{mg} / \mathrm{g})$ & $K_{L}(\mathrm{~L} / \mathrm{mg})$ & $R^{2}$ & & $K_{\mathrm{F}}(\mathrm{mg} / \mathrm{g})$ & $n$ & $R^{2}$ \\
\hline As $(\mathrm{V})$ & 85 & 20.3 & 0.818 & & 60.1 & 0.156 & 0.972 \\
As $(\mathrm{III})$ & 113 & 7.3 & 0.904 & & 70.5 & 0.205 & 0.981 \\
\hline
\end{tabular}


Table 2

Comparison of maximum arsenic sorption capacities for different adsorbents.

\begin{tabular}{|c|c|c|c|c|}
\hline Adsorbent & $\begin{array}{l}\text { As Equil.Con. range } \\
(\mathrm{mg} / \mathrm{L})\end{array}$ & $\begin{array}{l}\text { Max. As(III) sorption capacity } \\
(\mathrm{mg} / \mathrm{g})\end{array}$ & $\begin{array}{l}\text { Max. As(V) sorption capacity } \\
(\mathrm{mg} / \mathrm{g})\end{array}$ & Ref \\
\hline CuO nanoparticles & $0-100$ & $26.9(\mathrm{pH} 8.0)$ & $22.6(\mathrm{pH} 8.0)$ & Martinson and Reddy [16] \\
\hline $\mathrm{MnO}_{2}$ & $0-40$ & $14.8(\mathrm{pH} 7.0)$ & $7.8(\mathrm{pH} \mathrm{7.0)}$ & Chen et al. [21] \\
\hline Ce-Mn binary oxide & $0-40$ & $97.7(\mathrm{pH} 7.0)$ & $63.6(\mathrm{pH} 7.0)$ & Chen et al. [21] \\
\hline Fe-Mn binary oxide & $0-40$ & $100(\mathrm{pH} \mathrm{6.9)}$ & $53.9(\mathrm{pH} 6.9)$ & Zhang et al. [17] \\
\hline Ce-Ti oxide & $0-14$ & $55.3(\mathrm{pH} 6.5)$ & $44.9(\mathrm{pH} 6.5)$ & Li et al. [18] \\
\hline Fe-Zr binary oxide & $0-40$ & $120(\mathrm{pH} 7.0)$ & $46.1(\mathrm{pH} 7.0)$ & Ren et al. [34] \\
\hline Zr-Mn binary oxide & $0-30$ & $105(\mathrm{pH} \mathrm{5.0)}$ & $80.0(\mathrm{pH} 5.0)$ & Zhang et al., [19] \\
\hline Fe-Cu binary oxide & $0-60$ & $122(\mathrm{pH} 7.0)$ & $82.7(\mathrm{pH} 7.0)$ & Zhang et al., [27] \\
\hline Ti-Mn binary oxide & $0-60$ & $107(\mathrm{pH} 7.0)$ & $87.2(\mathrm{pH} 7.0)$ & Zhang et al., [33] \\
\hline Al-Ti-Mn trimetal oxide & $0-300$ & $203(\mathrm{pH} 7.0)$ & $147(\mathrm{pH} 7.0)$ & Thanh et al. [22] \\
\hline Co-Al-Fe nano adsorbent & $0-120$ & $130(\mathrm{pH} 7.0)$ & $76(\mathrm{pH} 7.0)$ & Penke et al. [23] \\
\hline $\mathrm{Fe}-\mathrm{Ni}-\mathrm{Mn}$ trimetal oxide & $0-70$ & $81.9(\mathrm{pH} 7.0)$ & N.A. & Nasir et al. [24] \\
\hline Fe-Mn-La-impregnated biochar & $0-40$ & 15.3 (N.A.) & N.A. & Lin et al. [26] \\
\hline Fe-Ti-Mn oxide & $0-30$ & $120(7.0)$ & $75.5(\mathrm{pH} 7.0)$ & Zhang et al. [25] \\
\hline $\mathrm{FeMnO}_{\mathrm{x}} / \mathrm{SBA}-15$ & $0-10$ & $27.6(7.0)$ & $30.5(7.0)$ & Zhou et al., [35] \\
\hline $\mathrm{Fe}-\mathrm{Cu}-\mathrm{Mn}$ trimetal oxide & $0-40$ & $131(7.0)$ & $105(\mathrm{pH} \mathrm{7.0)}$ & Present study \\
\hline
\end{tabular}

N.A.: not available.

where $q_{\mathrm{e}}$ and $q_{\mathrm{t}}$ are the adsorbed amounts of arsenic per unit weight of the sorbent $(\mathrm{mg} / \mathrm{g})$ at equilibrium and at time $\mathrm{t}(\mathrm{h})$, respectively, $k_{1}$ $\left(\mathrm{h}^{-1}\right)$ and $k_{2}[\mathrm{mg} /(\mathrm{g} \cdot \mathrm{h})]$ are the pseudo-first-order and pseudo-
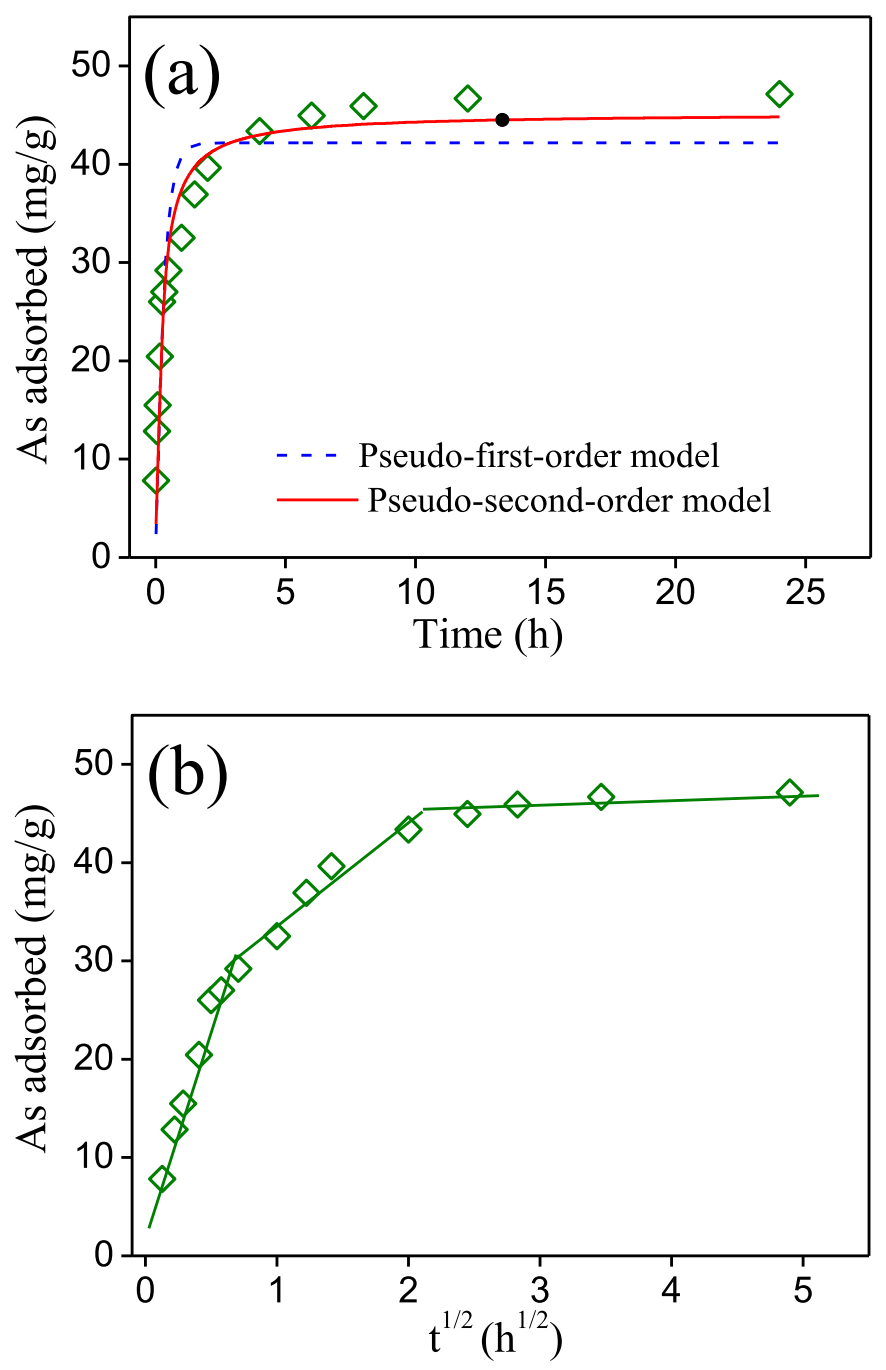

Fig. 3. Kinetics of As(III) sorption on the Fe-Cu-Mn trimetal oxide, (a) fitted with pseudofirst order model and pseudo-second order model and (b) fitted with intraparticle diffusion model. Initial As(III) concentration $=10 \mathrm{mg} / \mathrm{L}$, sorbent dose $=200 \mathrm{mg} / \mathrm{L}$, $\mathrm{pH}=7.0 \pm 0.1$ and $\mathrm{T}=25 \pm 1{ }^{\circ} \mathrm{C}$. second-order rate constants, respectively. The parameter values are listed in Table S1. The high $R^{2}$ value proves that the kinetic data are better described by the pseudo-second order equation. This suggests that the As(III) removal might be chemisorption.

Sorption is a multi-step process, including axial convection, external film mass transport, intraparticle diffusion, and binding on the surface of materials [36]. However, the pseudo-second order model assumes that sorption is a binding process achieved in one step [37]. Therefore, the kinetic data were also fitted using the intraparticle diffusion model (Eq. (5)). It considers that sorption is a complicated process and consists of several different steps [37].

$q_{\mathrm{t}}=k_{\mathrm{p}} t^{0.5}+c$

where $q_{\mathrm{t}}$ is the adsorbed amount of arsenic per unit weight of the sorbent at any time $\mathrm{t}(\mathrm{h}) . \mathrm{kp}$ is the rate constant, $C$ is a constant, representing the effect of boundary layer. The values of $k$ p and $C$ could be obtained from the plot of $q_{\mathrm{t}}$ versus $t^{0.5}$. If intraparticle diffusion is the rate-controlling step, this plot should be a straight line and pass through the original point [38]. The plot is nonlinear and contains three linear sections (Fig. 3b). This indicates that there are three stages in sorption process: fast, moderate, and slow, being dominated by external mass transfer, intraparticle diffusion and steric hindrance from the sorbed arsenic molecules, respectively. This implies that the As(III) sorption by the ICM is a multi-step process and intraparticle diffusion is not the rate-controlling step.

\subsubsection{Influence of $\mathrm{pH}$ and ionic strength}

Fig. 4 depicts the influence of solution $\mathrm{pH}$ and ionic strength on As (III) uptake by the ICM. The sorption of As(III) is effective over a wide range of $\mathrm{pH} 3-10$ and it decreases as the solution $\mathrm{pH}$ increases. This phenomenon is not in agreement with the results of typical As(III) sorption on the metal oxides [39], in which it rises slowly when the $\mathrm{pH}$ value ascends and reaches its maximal value at $\mathrm{pH}$ close to $\mathrm{p} k_{\mathrm{a} 1}$ of arsenious acid (9.2). However, the trend is very similar to that of $\mathrm{As}(\mathrm{V})$ sorption on the iron (hydr)oxides and compound oxides [27,40], indicating the As(III) has been oxidized to $\mathrm{As}(\mathrm{V})$ by the ICM. The relatively poor sorption of As(III) at high pH may be ascribed to strong repulsion between the produced anions of $\mathrm{As}(\mathrm{V})$ and the negatively charged surface of trimetal oxide.

Fig. 4 illustrates that the change of ionic strength does not significantly alter the sorption of As(III). This indicates that the removal of As(III) achieved through specific sorption associated with the formation of inner sphere complexes, because the sorption of anions via innersphere binding either is not greatly sensitive to ionic strength or increases with a higher ionic strength [41]. 


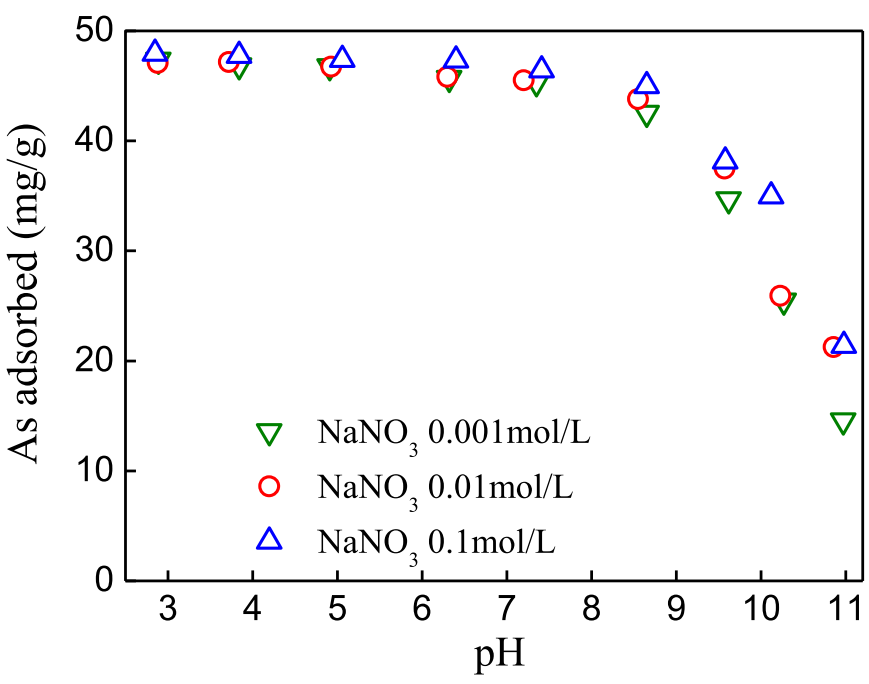

Fig. 4. Influence of $\mathrm{pH}$ and ionic strength on $\mathrm{As}(\mathrm{III})$ sorption by Fe-Cu-Mn trimetal oxide Initial As(III) concentration $=10 \mathrm{mg} / \mathrm{L}$, sorbent dose $=200 \mathrm{mg} / \mathrm{L}$ and $\mathrm{T}=25 \pm 1{ }^{\circ} \mathrm{C}$.

\subsubsection{Effect of co-existing ions on As(III) sorption}

The effect of common co-existing cations and anions $\left(\mathrm{Ca}^{2+}, \mathrm{Mg}^{2+}\right.$, $\mathrm{Cl}^{-}, \mathrm{SO}_{4}^{2}, \mathrm{CO}_{3}^{2-}, \mathrm{SiO}_{3}^{2-}$ and $\mathrm{PO}_{4}^{3-}$ ) on $\mathrm{As}(\mathrm{III})$ sorption is illustrated in Fig. S2. The present $\mathrm{Ca}^{2+}, \mathrm{Mg}^{2+}, \mathrm{Cl}^{-}, \mathrm{SO}_{4}^{2}$ and $\mathrm{CO}_{3}^{2-}$ did not significantly affect $\mathrm{As}(\mathrm{III})$ sorption. However, the coexisting $\mathrm{SiO}_{3}^{2-}$ and $\mathrm{PO}_{4}^{3-}$ posed greatly negative impact on $\mathrm{As}$ (III) sorption, particularly at high concentration levels. Evidently, the $\mathrm{PO}_{4}^{3-}$ caused a more remarkable decrease in As (III) sorption. This strong interfering effect of $\mathrm{PO}_{4}^{3-}$ in the arsenic sorption may be attributed to the similarity in chemistry and molecular structure between them, which results in an intensive competition between phosphate and arsenic anions for sorptive sites on the surface of ICM.

\subsection{Regeneration and reusability}

Reusability is a very important parameter of sorbents for practical applications. To estimate the reusability of ICM, desorption of arsenicloaded adsorbent using $\mathrm{NaOH}$ solution and re-adsorption experiments had been carried out. Fig. S3 demonstrates the results of consecutive sorption-regeneration ( 4 cycles) experiments. The value of cycle 0 corresponds to the $\mathrm{As}(\mathrm{III})$ removal percentage of the virgin ICM. The sorption of $\mathrm{As}(\mathrm{III})$ decreases with an increase in cycling number. Nevertheless, the reduction is insignificant and after the forth desorption, the As(III) removal percentage is still as high as $82 \%$ and over $90 \%$ of the original sorption capacity is maintained. These suggest that the active sorption sites of spent ICM can be easily restored through $\mathrm{NaOH}$ solution treatment and the as-synthesized sorbent can be reused repeatedly. It is worth noting that no extra oxidant was employed to restore the oxidability of ICM in the regeneration process. The reason is that the regeneration was done in an air-opened system and the $\mathrm{Mn}^{2}$ + adsorbed on the surface of ICM which originated from the reductive dissolution of $\mathrm{MnO}_{2}$ in the composite, could be easily oxidized to $\mathrm{Mn}^{4}$ + by the oxygen in the air under alkaline conditions.

\subsection{Surface analysis of ICM before and after As(III) sorption}

\subsubsection{Zeta potential analysis}

Fig. S4 presents the zeta potentials of ICM before and after treatment with As(III) solution. The isoelectric point (IEP) of the original oxide is approximately 8.1, which shifts to around 7.0 after As(III) sorption. The pure sorption of uncharged $\mathrm{H}_{3} \mathrm{AsO}_{3}$ does not significantly alter the IEP of sorbents [34]. However, specific sorption of anions may produce a more negatively charged surface of sorbents and consequently shift the IEP to lower $\mathrm{pH}$ values $[42,43]$. This also implies that uncharged As
(III) has been converted to $\mathrm{As}(\mathrm{V})$ during its sorption process, which exists mainly in negatively charged species at $\mathrm{pH}$ values tested. Therefore, it can be concluded that specific sorption of $\mathrm{As}(\mathrm{V})$ rather than purely electrostatic interaction occurs at the trimetal oxide/aqueous interface, which results in a drop of IEP.

\subsubsection{FTIR spectra analysis}

Fig. 5 shows the FTIR spectra of ICM before and after treatment with As (III). For the virgin trimetal oxide, the broad strong band in the region $3500-3000 \mathrm{~cm}^{-1}$ is associated to the vibration of $\mathrm{O}-\mathrm{H}$ stretching of surface metal hydroxyl and water molecule, and the peak at $1624 \mathrm{~cm}^{-1}$ is due to the bending vibration of $\mathrm{H}-\mathrm{O}-\mathrm{H}$ (water molecule), indicating that physisorbed water exists on the surface of ICM; the peaks at 1099, 1046 , and $970 \mathrm{~cm}^{-1}$ might be attributed to the vibration of $\mathrm{SO}_{4}^{2-}$ [44]. After reaction, the bands at $3500-3000 \mathrm{~cm}^{-1}$ and $1624 \mathrm{~cm}^{-1}$ had no significant change, whereas the peaks at 1099, 1046, and $970 \mathrm{~cm}^{-1}$ almost completely disappeared. At the same time, a new peak has been observed at $816 \mathrm{~cm}^{-1}$, which can be owing to the vibration of $\mathrm{As}(\mathrm{V})-\mathrm{O}-\mathrm{M}$ groups [45]. This is also indicative of oxidation of As(III) in the sorption process. The FTIR results further confirm the specific sorption of arsenic, in which the $\mathrm{As}(\mathrm{V})$ anions mainly replace the hydroxyl and sulfate groups on the surface of the trimetal oxide.

\subsubsection{XPS spectra analysis}

To further determine the valence state of sorbed arsenic and investigate the change of surface compositions, XPS spectra of the ICM before and after As(III) uptake were collected and analyzed. The As3d, Mn2p, 01s and S2p narrow scans are depicted in Fig. 6 and the peak parameters are summarized in Table S2.

For the virgin ICM, no peak can be observed at binding energy in the range of $42-47 \mathrm{eV}$. After As(III) treatment, a new peak appears at binding energy of about $44.8 \mathrm{eV}$ (Fig. 6a), implying the presence of arsenic sorbed on the surface of ICM. The fitting results show that the As3d core level can be divided into two components, possessing binding energies of 44.3 and $45.2 \mathrm{eV}$, respectively. The binding energy of As3d core level for $\mathrm{As}(\mathrm{III})$ is $44.3-44.5 \mathrm{eV}$, while $\mathrm{As}(\mathrm{V})$ is $45.2-45.6 \mathrm{eV}$ [46-48]. This suggests that $\mathrm{As}(\mathrm{III})$ and $\mathrm{As}(\mathrm{V})$ species are coexisting on the surface of trimetal oxide. According to XPS analysis, approximately $65.1 \%$ of $\mathrm{As}(\mathrm{III})$ was converted to $\mathrm{As}(\mathrm{V})$ under tested conditions (Table S2). The incomplete oxidation of As(III) might be ascribed to the low dosage of trimetal oxide ( $200 \mathrm{mg} / \mathrm{L}$ ) and high initial As(III) concentration $(40 \mathrm{mg} / \mathrm{L})$.

The oxidation state of Mn in the original and As(III) treated ICM was analyzed. Fig. 6b illustrates the fitting results. As can be seen, only Mn (IV) and Mn(III) species are present in the virgin ICM [29,46]. The

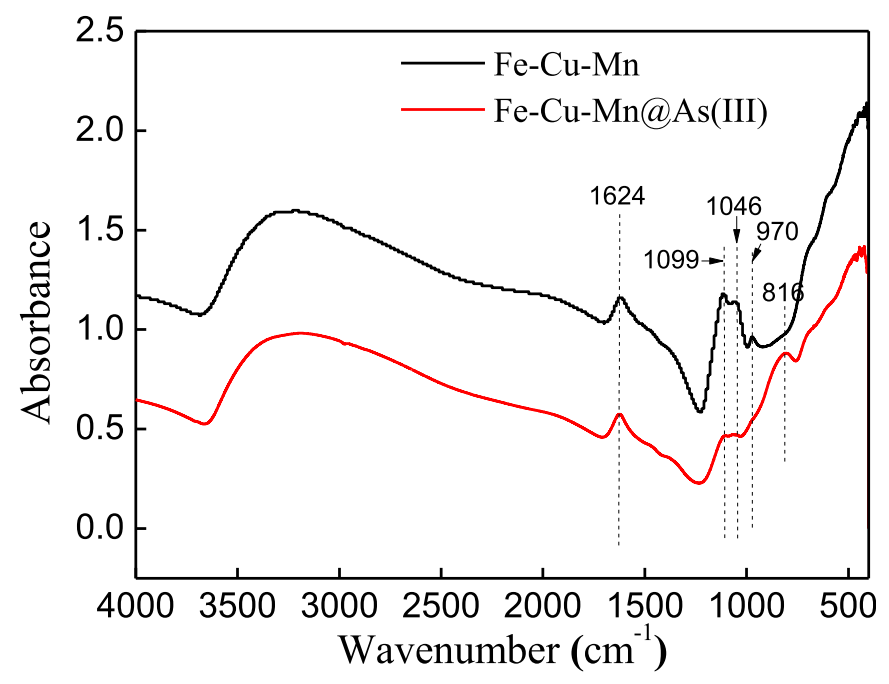

Fig. 5. FTIR spectra of Fe-Cu-Mn trimetal oxide before and after $\mathrm{As}(\mathrm{III})$ sorption. 

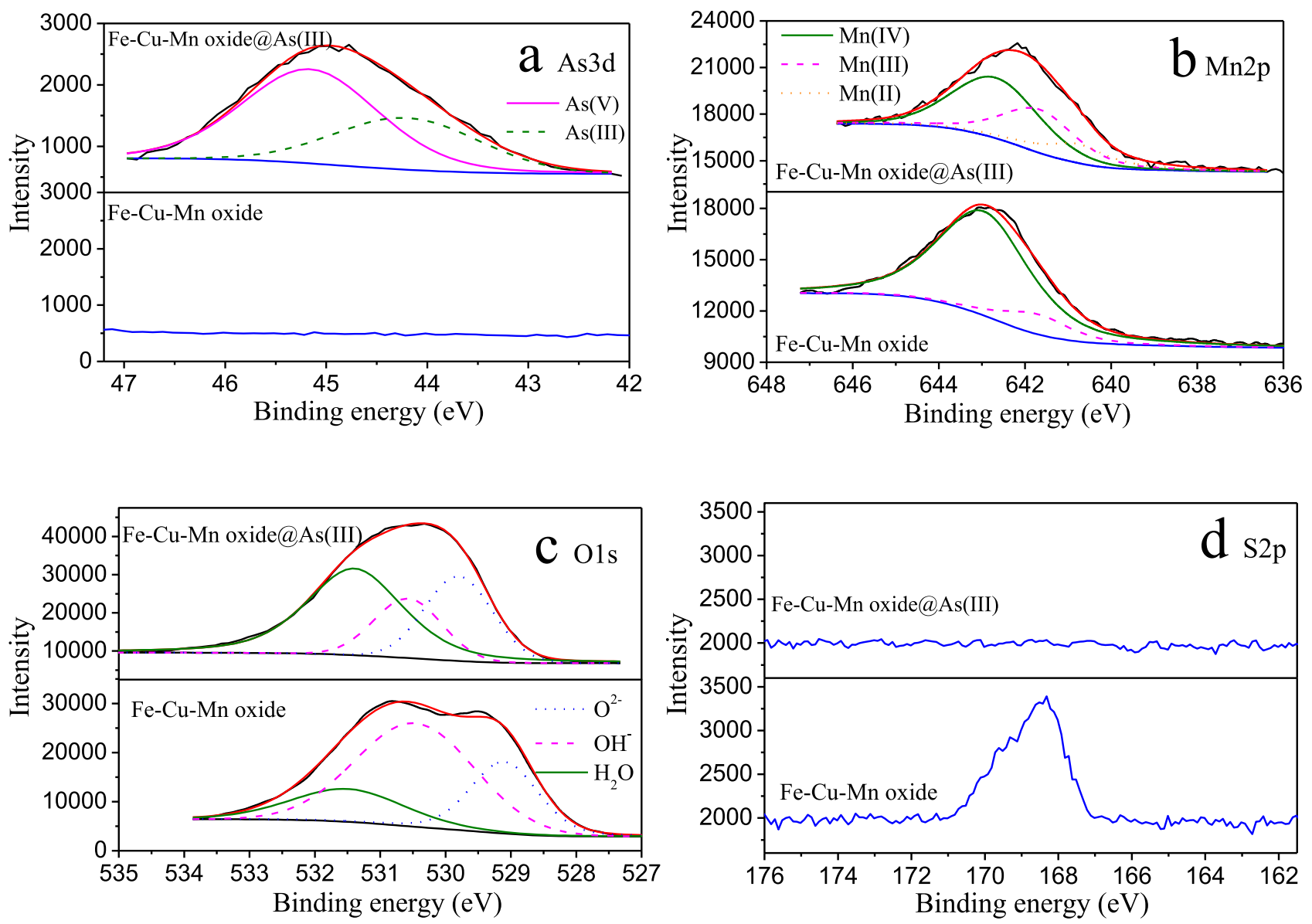

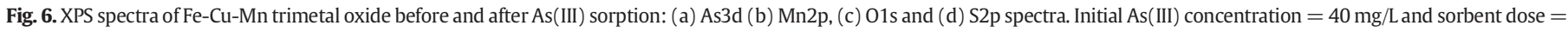
$200 \mathrm{mg} / \mathrm{L}, \mathrm{pH}=7.0$.

contents of $\mathrm{Mn}$ (IV) and $\mathrm{Mn}$ (III) are 87.6 and $12.4 \%$, respectively. Clearly, $\mathrm{MnO}_{2}$ is the dominant species, which meets the aim of development this trimetal oxide. After reaction with As(III), the content of Mn(IV) reduces from 87.6 to $50.7 \%$, while the content of $\mathrm{Mn}$ (III) increases to 33.7\%. Moreover, $\mathrm{Mn}(\mathrm{II})$ species appears and its content accounts for $15.6 \%$. The decline in Mn(IV) content and corresponding increase in reduced $\mathrm{Mn}$ species ( $\mathrm{Mn}(\mathrm{III})$ and $\mathrm{Mn}(\mathrm{II})$ ) might be ascribed to the oxidation-reduction reaction between $\mathrm{MnO}_{2}$ and $\mathrm{As}(\mathrm{III})$, in which the $\mathrm{MnO}_{2}$ was firstly reduced to $\mathrm{MnOOH}$ by $\mathrm{As}(\mathrm{III})$ and the formed $\mathrm{MnOOH}$ was further reduced to $\mathrm{Mn}^{2+}$ [46]. Additionally, the oxidation states of Fe and $\mathrm{Cu}$ in the ICM before and after As(III) treatment were also studied. The results are displayed in Fig. S5. For the original oxide, the binding energies of $\mathrm{Fe} 2 \mathrm{p}_{3 / 2}$ and $\mathrm{Cu} 2 \mathrm{p}_{3 / 2}$ are 711.4 and $934.5 \mathrm{eV}$, respectively, suggesting the valences of $\mathrm{Fe}$ and $\mathrm{Cu}$ are respectively +3 and +2 . After $\mathrm{As}$ (III) sorption, the binding energies of $\mathrm{Fe} 2 \mathrm{p}_{3 / 2}$ and $\mathrm{Cu} 2 \mathrm{p}_{3 / 2}$ do not significantly shift, which are 711.2 and $934.2 \mathrm{eV}$, respectively. This shows that no change occurs in the oxidation states of $\mathrm{Fe}$ and $\mathrm{Cu}$ during As(III) sorption. It can be reasonably concluded that the Fe oxide and $\mathrm{CuO}$ in the trimetal oxide performed mainly as the capturers for arsenic rather than oxidants in the process of As(III) removal.

The 01s core level spectra (Fig. 6c) may be decomposed into three peaks, corresponding to lattice oxygen $\left(\mathrm{O}^{2-}\right)$, hydroxyl $(-\mathrm{OH})$, and sorbed water $\left(\mathrm{H}_{2} \mathrm{O}\right)$, respectively. For the virgin ICM, the content of $\mathrm{OH}$ accounts for $56.7 \%$. It decreases to $20.2 \%$ after reaction with $\mathrm{As}(\mathrm{III})$. Meanwhile, the percentage of $\mathrm{O}^{2-}$ increases from 24.5 to $28.8 \%$. These indicate that the hydroxyl groups were partially replaced by arsenic during As(III) removal. Fig. 6d displays the S2p core level spectra before and after As(III) sorption. The original trimetal oxide exhibits a binding energy for $\mathrm{S}_{2} \mathrm{p}_{3 / 2}$ at $168.4 \mathrm{eV}$, which is associated with $\mathrm{S}-\mathrm{O}$ bonds in sulfate species. After sorption, the peak at $168.4 \mathrm{eV}$ disappears completely, indicating that the sulfates on the surface of trimetal oxide were complete exchanged by the arsenic. This result is consistent with the one of FTIR analysis.

\subsection{As(III) sorption mechanism}

From above-mentioned analyses, it might be deduced that the uptake of As(III) is a complicated process, involving in both adsorption and surface redox reaction. The whole process might be described in the following section. (i) As(III) is initially transported to the solidwater interface by diffusion and then sorbed onto the solid surface through replacing the sulfate and surface hydroxyl groups. (ii) The sorbed $\mathrm{As}(\mathrm{III})$ is afterwards oxidized to $\mathrm{As}(\mathrm{V})$ by the $\mathrm{MnO}_{2}$ content in the ICM, being accompanied by the detachment of $\mathrm{As}(\mathrm{V})$ and $\mathrm{Mn}(\mathrm{II})$ from the surface of the solid into water. (iii) The dissolved $\mathrm{As}(\mathrm{V})$ is then sorbed by replacing the surface hydroxyl groups or adsorbed As (III) species, forming inner-sphere complexes. The Mn(II) in water can be also sorbed to the solid surface. This process repeats again and again until $\mathrm{As}$ (III) species or available $\mathrm{MnO}_{2}$ is exhausted. The possible mechanism of As(III) sorption by the ICM is show in Fig. 7.

\section{Conclusions}

A novel ICM sorbent was fabricated using a simultaneous oxidation and co-precipitation approach. The as-prepared sorbent can efficiently oxidize $\mathrm{As}(\mathrm{III})$ to $\mathrm{As}(\mathrm{V})$ and adsorb the formed $\mathrm{As}(\mathrm{V})$. The maximal uptake capacity of As(III) reaches $131 \mathrm{mg} / \mathrm{g}$ at pH about 7.0, which is competitive with the majority of sorbents reported. Lower $\mathrm{pH}$ is favorable 


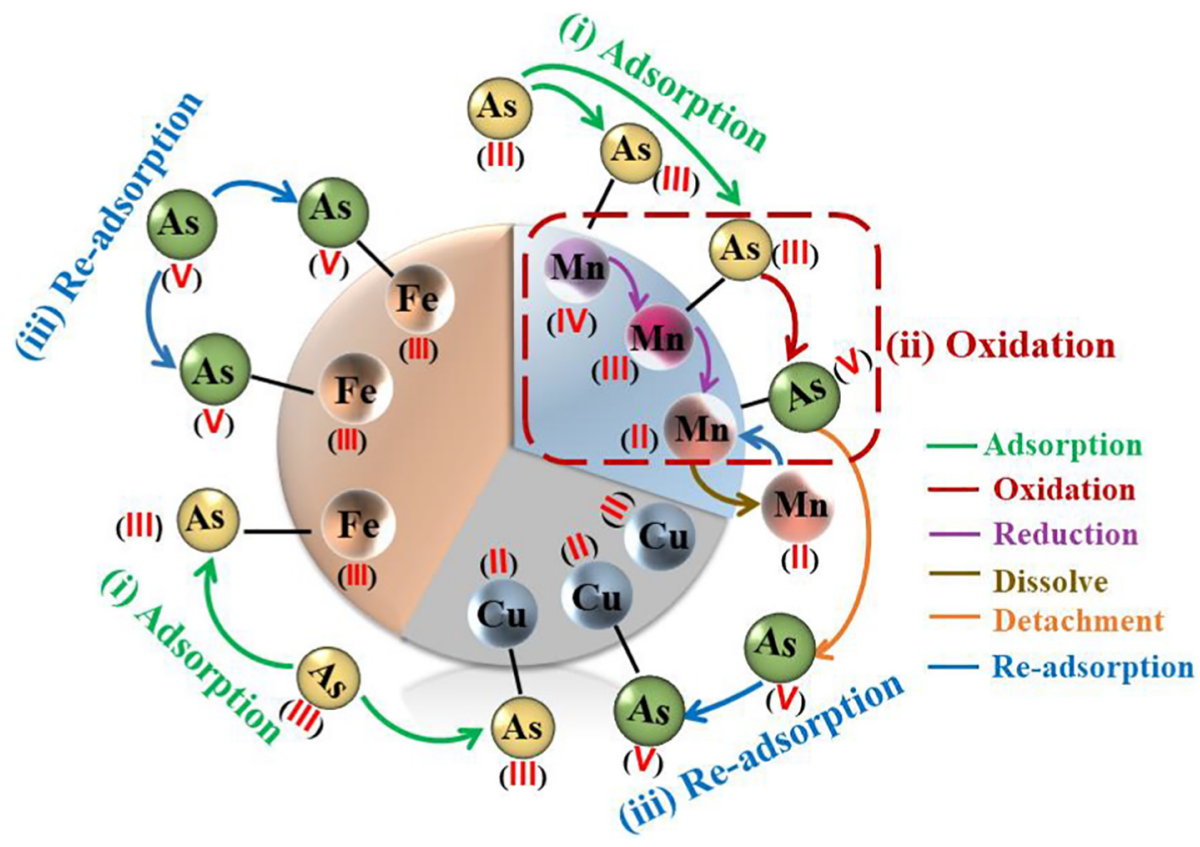

Fig. 7. The possible mechanisms of $\mathrm{As}(\mathrm{III})$ uptake by Fe-Cu-Mn trimetal oxide.

for $\mathrm{As}$ (III) sorption and it drops gradually as solution $\mathrm{pH}$ increases. The ICM has a relatively high selectivity for arsenic. The arsenic-containing sorbent could be readily regenerated with dilute $\mathrm{NaOH}$ solution. As (III) removal is accomplished via an oxidation coupled with adsorption process, in which inner-sphere surface complexes are formed. The Mn oxide content acts mainly as an oxidant for $\mathrm{As}(\mathrm{III})$ to $\mathrm{As}(\mathrm{V})$, whereas the Fe oxide and $\mathrm{Cu}$ oxide play a significant role in adsorbing the arsenic. The ICM might be used as an alternative sorbent for removing arsenic from waters, due to its good performance, low cost, facile synthesis and high reusability.

\section{CRediT authorship contribution statement}

Gaosheng Zhang:Conceptualization, Writing - original draft.Ye Liu: Investigation, Validation.Jianyan Wang:Investigation.Huosheng Li: Writing - review \& editing.

\section{Declaration of competing interest}

The authors declare that they have no known competing financial interests or personal relationships that could have appeared to influence the work reported in this paper.

\section{Acknowledgements}

The authors acknowledge the financial support from National Natural Science Foundation of China (Nos. 51678562 and 51478457).

\section{Appendix A. Supplementary data}

Supplementary data to this article can be found online at https://doi. org/10.1016/j.molliq.2020.112993.

\section{References}

[1] K.G. Brown, G.L. Ross, Arsenic, drinking water, and health: a position paper of the American Council on Science and Health, Regul. Toxicol. Pharmacol. 36 (2002) $162-174$.

[2] L.C. Roberts, S.J. Hug, T. Ruettimann, A.W. Khan, M.T. Rahman, Arsenic removal with iron (II) and iron (III) in waters with high silicate and phosphate concentrations, Environ. Sci. Technol. 38 (2004) 307-315.
[3] T.G. Asere, C.V. Stevens, G.D. Laing, Use of (modified) natural adsorbents for arsenic remediation: a review, Sci. Total Environ. 676 (2019) 706-720.

[4] P.L. Smedley, D.G. Kinniburgh, A review of the source, behavior and distribution of arsenic in natural waters, Appl. Geochem. 17 (2002) 517-568.

[5] N.E. Korte, Q. Fernando, A review of arsenic(III) in groundwater, Crit. Rev. Environ. Control. 21 (1991) 1-39.

[6] Y.X. Wang, J.M. Duan, W. Li, S. Beecham, D. Mulcahy, Aqueous arsenite removal by simultaneous ultraviolet photocatalytic oxidation-coagulation of titanium sulfate, J. Hazard. Mater. 303 (2016) 162-170.

[7] J.R. Huling, S.G. Huling, R. Ludwig, Enhanced adsorption of arsenic through the oxidative treatment of reduced aquifer solids, Water Res. 123 (2017) 183-191.

[8] J. Shadbahr, T. Husain, Affordable and efficient adsorbent for arsenic removal from rural water supply systems in Newfoundland, Sci. Total Environ. 660 (2019) 158-168.

[9] J.L. Alvarez-Cruz, S.E. Garrido-Hoyos, Effect of the mole ratio of Mn/Fe composites on arsenic (V) adsorption, Sci. Total Environ. 668 (2019) 47-55.

[10] M.L. Pierce, C.B. Moore, Adsorption of arsenite and arsenate on amorphous iron hydroxide, Water Res. 16 (1982) 1247-1253.

[11] M.E. Pena, G.P. Korfiatis, M. Patel, L. Lippincott, X.G. Meng, Adsorption of As(V) and As(III) by nanocrystalline titanium dioxide, Water Res. 39 (2005) 2327-2337.

[12] R. Li, Q. Li, S. Gao, J.K. Shang, Exceptional arsenic adsorption performance of hydrous cerium oxide nanoparticles: part A. Adsorption capacity and mechanism, Chem. Eng. J. 185-186 (2012) 127-135.

[13] V. Lenoble, C. Laclautre, B. Serpaud, V. Deluchat, J.C. Bollinger, As(V) retention and As (III) simultaneous oxidation and removal on a $\mathrm{MnO}_{2}$-loaded polystyrene resin, Sci. Total Environ. 326 (2004) 197-207.

[14] J.M. Luo, X.Y. Meng, J. Crittenden, J.H. Qu, C.Z. Hu, H.J. Liu, P. Peng, Arsenic adsorption on $\alpha-\mathrm{MnO}_{2}$, nanofibers and the significance of (100) facet as compared with (110), Chem. Eng. J. 331 (2018) 492-500.

[15] C. Hang, Q. Li, S.A. Gao, J.K. Shang, As(III) and As(V) adsorption by hydrous zirconium oxide nanoparticles synthesized by a hydrothermal process followed with heat treatment, Ind. Eng. Chem. Res. 51 (2012) 353-361.

[16] C.A. Martinson, K.J. Reddy, Adsorption of arsenic(III) and arsenic(V) by cupric oxide nanoparticles, J. Colloid Interface Sci. 336 (2009) 406-411.

[17] G.S. Zhang, J.H. Qu, H.J. Liu, R.P. Liu, R.C. Wu, Preparation and evaluation of a novel Fe-Mn binary oxide adsorbent for effective arsenite removal, Water Res. 41 (2007) 1921-1928.

[18] Z.J. Li, S.B. Deng, G. Yu, J. Huang, V.C. Lim, As(V) and As(III) removal from water by a Ce-Ti oxide adsorbent: behavior and mechanism, Chem. Eng. J. 161 (2010) 106-113.

[19] G.S. Zhang, A. Khorshed, J.P. Chen, Simultaneous removal of arsenate and arsenite by a nanostructured zirconium-manganese binary hydrous oxide: behavior and mechanism, J. Colloid Interface Sci. 397 (2013) 137-143.

[20] S.W. Liu, S.H. Kang, G.Z. Wang, H.J. Zhao, W.P. Cai, Micro/nanostructured porous FeNi binary oxide and its enhanced arsenic adsorption performances, J. Colloid Interface Sci. 458 (2015) 94-102.

[21] J. Chen, J.Y. Wang, G.S. Zhang, Q.Y. Wu, D.T. Wang, Facile fabrication of nanostructured cerium-manganese binary oxide for enhanced arsenite removal from water, Chem. Eng. J. 334 (2018) 1518-1526.

[22] D.N. Thanh, Z. Bastl, K. Černá, P. Ulbrich, J. Lederer, Amorphous nanosized Al-Ti-Mn trimetal hydrous oxides: synthesis, characterization and enhanced performance in arsenic removal, RSC Adv. 6 (2016) 100732-100742.

[23] Y.K. Penke, G. Anantharaman, J. Ramkumar, K.K. Kar, Aluminum substituted cobalt ferrite ( $\mathrm{Co}-\mathrm{Al}-\mathrm{Fe})$ nano adsorbent for arsenic adsorption in aqueous systems and 
detailed redox behavior study with XPS, ACS Appl. Mater. Interfaces 9 (2017) 11587-11598.

[24] A.M. Nasir, P.S. Goh, A.F. Ismail, Novel synergistic hydrous iron-nickel-manganese (HINM) trimetal oxide for hazardous arsenite removal, Chemosphere 200 (2018) 504-512.

[25] W. Zhang, C.H. Liu, L. Wang, T. Zheng, G.H. Ren, J. Li, J. Ma, G.S. Zhang, H.R. Song, Z.X. Zhang, Z.Y. Li, A novel nanostructured Fe-Ti-Mn composite oxide for highly efficient arsenic removal: preparation and performance evaluation, Colloids Surf. A Physicochem. Eng. Asp. 561 (2019) 364-372.

[26] L.N. Lin, G.G. Zhang, X.W. Liu, Z.H. Khan, W.W. Qiu, Z.G. Song, Synthesis and adsorption of Fe-Mn-La-impregnated biochar composite as an adsorbent for As(III) removal from aqueous solutions, Environ. Pollut. 247 (2019) 128-135.

[27] G.S.Zhang, Z.M. Ren, X.W. Zhang, J. Chen, Nanostructured iron(III)-copper(II) binary oxide: a novel adsorbent for enhanced arsenic removal from aqueous solutions, Water Res. 47 (2013) 4022-4031.

[28] D.W. Oscarson, P.M. Huang, C. Defosse, A. Herbillon, Oxidative power of Mn(IV) and $\mathrm{Fe}$ (III) oxides with respect to $\mathrm{As}(\mathrm{III})$ in terrestrial and aquatic environments, Nature 291 (1981) 50-51.

[29] B.A. Manning, S.E. Fendorf, B. Bostick, D.L. Suarez, Arsenic(III) oxidation and arsenic (V) adsorption reactions on synthetic birnessite, Environ. Sci. Technol. 36 (2002) 976-981.

[30] B. Zhi, H. Ding, D.M. Wang, Y. Cao, Y. Zhang, X. Wang, Y.L. Liu, Q.S. Huo, Ordered mesoporous $\mathrm{MnO}_{2}$ as a synergetic adsorbent for effective arsenic(III) removal, J. Mater. Chem. A 2 (2014) 2374-2382.

[31] J. Hou, Y. Xiang, D. Zheng, Y. Li, S. Xue, C. Wu, W. Tan, Morphology-dependent enhancement of arsenite oxidation to arsenate on birnessite-type manganese oxide, Chem. Eng. J. 327 (2017) 235-243.

[32] G.S. Zhang, H.J. Liu, R.P. Liu, J.H. Qu, Adsorption behavior and mechanism of arsenate at Fe-Mn binary oxide/water interface, J. Hazard. Mater. 168 (2009) 820-825.

[33] W. Zhang, C.H. Liu, T. Zheng, J. Ma, G.S. Zhang, G.H. Ren, L. Wang, Y.L. Liu, Efficient oxidation and sorption of arsenite using a novel titanium(IV)-manganese(IV) binary oxide sorbent, J. Hazard. Mater. 353 (2018) 410-420.

[34] Z.M. Ren, G.S. Zhang, J.P. Chen, Adsorptive removal of arsenic from water by an ironzirconium binary oxide adsorbent, J. Colloid Interface Sci. 358 (2011) 230-237.

[35] J.S. Zhou, X.X. Zhou, K.L. Yang, Z. Cao, Z.N. Wang, C.C. Zhou, S.A. Baig, X.H. Xu, Adsorption behavior and mechanism of arsenic on mesoporous silica modified by iron-manganese binary oxide (FeMnOx/SBA-15) from aqueous systems, J. Hazard. Mater. 384 (2020) 121229.
36] M. Badruzzaman, P. Westerhoff, D.R.U. Knappe, Intraparticle diffusion and adsorption of arsenate onto granular ferric hydroxide (GFH), Water Res. 38 (2004) 4002-4012.

[37] M. D'Arcy, D. Weiss, M. Bluck, R. Vilar, Adsorption kinetics, capacity and mechanism of arsenate and phosphate on a bifunctional $\mathrm{TiO}_{2}-\mathrm{Fe}_{2} \mathrm{O}_{3}$ bi-composite, J. Colloid Interface Sci. 364 (2011) 205-212.

[38] X.M. Dou, Y.S. Zhang, H.J. Wang, T.J. Wang, Y.L. Wang, Performance of granular zirconium-iron oxide in the removal of fluoride from drinking water, Water Res. 45 (2011) 3571-3578.

[39] W. Stumm, Chemistry of the Solid-Water Interface, Wiley-Interscience, New York, 1996.

[40] F.J. Hingston, A.M. Posner, J.P. Quirk, Anion adsorption by goethite and gibbsite, J. Soil Sci. 23 (1972) 177-192.

[41] M.B. McBride, A critique of diffuse double layer models applied to colloid and surface chemistry, Clay Clay Miner. 45 (1997) 598-608.

[42] T.H. Hsia, S.L. Lo, C.F. Lin, D.Y. Lee, Characterization of arsenate adsorption on hydrous iron oxide using chemical and physical methods, Colloids Surf. A Physicochem. Eng. Asp. 85 (1994) 1-7.

[43] W. Stumm, J.J. Morgan, Aquatic Chemistry: Chemical Equilibria and Rates in Natural Waters, third ed. John-Wiley \& Sons, New York, 1996.

[44] G. Lefèvre, In situ Fourier-transform infrared spectroscopy studies of inorganic ions adsorption on metal oxides and hydroxides, Adv. Colloid Interfac. 107 (2004) 109-123.

[45] S. Goldberg, C.T. Johnston, Mechanisms of arsenic adsorption on amorphous oxides evaluated using macroscopic measurements, vibrational spectroscopy, and surface complexation modeling, J. Colloid Interface Sci. 234 (2001) 204-216.

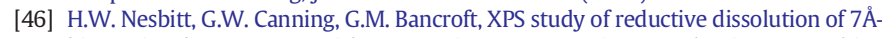
birnessite by $\mathrm{H}_{3} \mathrm{AsO}_{3}$ with constraints on reaction mechanism, Geochim. Cosmochim. Acta 62 (1998) 2097-2110.

[47] S. Ouvrard, P. Donato, M.O. Simonnot, S. Begin, J. Ghanbaja, M. Alnot, Y.B. Duval, F Lhote, O. Barres, M. Sardin, Natural manganese oxide: combined analytical approach for solid characterization and arsenic retention, Geochim. Cosmochim. Acta 69 (2005) 2715-2724.

[48] Y. Yu, C. Zhang, L. Yang, J.P. Chen, Cerium oxide modified activated carbon as an efficient and effective adsorbent for rapid uptake of arsenate and arsenite: material development and study of performance and mechanisms, Chem. Eng. J. 315 (2017) 630-638. 